\title{
PERANAN ORANGTUA DALAM MASA DEPAN ANAK
}

\author{
FELTA
}

\begin{abstract}
Abstrak
Pendidikan anak dimulai dari keluarga dan mendidik anak bermuara dari mengenal anak dan cara memperlakukan anak sesuai kebutuhannya dan perkembangannya. Keluarga merupakan pusat pendidikan yang utama bagi anak. Anak yang dibesarkan dilingkungan keluarga yang terdidik memiliki peluang yang besar untuk bertumbuh dengan baik. Karena dari keluarga setiap anak belajar dalam segala hal mulai dari cara anak belajar berbicara, berjalan, hingga anak belajar bagaimana caranya menjalani setiap kehidupan ke depannya. Fungsi ataupun tugas keluarga untuk mendidik anak-anak mereka agar menjadi pribadi-pribadi yang lebih baik. Setiap orang tua tentunya memiliki cara tersendiri dalam mendidik anak-anaknya. Rumah adalah sekolah bagi anak yang berfungsi untuk membentuk individu yang memiliki karakter dan sifat ideal dan menyiapkan mereka agar dapat hidup di masyarakat. Karena berbicara pendidikan bukan hanya menyangkut penyaluran pengetahuan tetapi juga pembentukan kepribadian, pembentukan karakter.
\end{abstract}

\section{LATAR BELAKANG}

Dukungan orangtua sangat penting dalam mewujudkan keberhasilan pendidikan buah hatinya. Namun, masih banyak orangtua yang kurang menyadari akan perannya dalam mendukung pendidikan anak dan menyerahkan sepenuhnya pada sekolah.

Hari Pendidikan Nasional yang diperingati setiap tanggal 2 Mei bukanlah menjadi seremonial milik siswa dan guru semata. Akan tetapi seluruh lapisan masyarakat, terutama orangtua ikut menyambutnya. Tak harus dengan mengikuti upacara bendera layaknya siswa, guru, dan lembaga yang berkecimpung dalam dunia pendidikan, namun sebagai momen untuk melakukan refleksi mengenai pendidikan di negeri ini. Terutama, pendidikan pada buah hati.

Dunia intersubjektif ikut andil dalam menentukan kehidupan anak-anak remaja dalam lingkungan masyarakat. Artinya, tabiat, sifat, dan perilaku anak-anak remaja dipengaruhi oleh budaya dalam lingkungannya. Budaya tersebut termanifestasi dalam mengelola dan memengaruhi pembawaan sifat dan perilaku para remaja. Hal ini sejalan dengan pendapat Ritzer (dalam Susiati, et.al, 2021), dunia intersubjektif menciptakan suatu realitas sosial yang dipaksa oleh struktur budaya dan lingkungan sosial ciptaan leluhur mereka sebelumnya (hal. 35). Oleh karena itu, pada diri remaja diperlukan sosialisasi dan internalisasi nilai-nilai semenjak mereka masih kecil. Ritzer (2014) mengatakan bahwa syarat dan fungsi bagi terpeliharanya integritas pola nilai di dalam sistem adalah proses internalisasi dan sosialisasi (hal. 86). Susiati (2019) mengatakan bahwa manusia adalah makhluk sosial yang perkembangan jiwanya tidak ditentukan sejak lahir tetapi dibentuk oleh lingkungannya. Lingkungan manusia itulah yang disebut kebudayaan (hal. 117).

Pendidikan merupakan pilar penting dalam perkembangan kognisi anak. Sejak dimulainya peradaban manusia disitu pulalah pendidikan muncul. Pendidikan adalah 
suatu runtunan dalam cara pemerolehan ilmu dan penyempurnaan diri yang dilakukan manusia secara terus menerus atau berkelanjutan. Manusia tidak luput dari keterbatasan dan kekurangan sehingga untuk melengkapi keterbatasan dan kekurangan yang dimiliki tersebut, manusia harus berproses, salah satunya melalui pemerolehan ilmu melalui pendidikan. Pendidikan yang diperoleh oleh manusia tidak hanya melalui pendidikan formal tetapi pendidikan awal yang didapatkan oleh manusia adalah melalui lingkungan keluarga dan lingkungan masyarakat (Tuasalamony et.al, 2020).

Peranan orang tua dalam membentuk suatu karakter anak sangatlah penting sebab pertama kali anak menerima sosialisasi dari lembaga keluarga. orang tua merupakan cerminan dari anak sehingga anak akan menjadi apa nantinya bergantung dari cara didikan orang tua terutama karakter khususnya dalam sikap religiusitas anak dalam bermasyarakat. Pendidikan beragama juga sangat penting diberikan kepada anak karena hal tersebut dapat menjadi bekal seorang anak dalam kehidupan bermasyarakat kelak. Peran orang tua dalam memberikan pendidikan religiusitas kepada anak sangat terlihat. Pendidikan religiusitas sangat penting bagi mereka untuk didapatkan oleh anak pada usia dini. Bagi para orang tua, dengan pendidikan agama yang diberikan kepada anak, dapat memberikan pemahaman tentang baik buruk dalam masyarakat sehingga anakanak tersebut kelak tidak terjerumus dalam hal-hal yang bersifat negatif (Buton, et.al, 2020)

Sayangnya, tak banyak orangtua menyadari bahwa perannya dalam mendukung pendidikan anak sangat mempengaruhi keberhasilan anak dalam belajar dan bersosialisasi. Tak ayal, banyak yang menyerahkan pendidikan anak sepenuhnya kepada pihak sekolah. Padahal, untuk mewujudkan keberhasilan pendidikan, dibutuhkan sinergi yang harmonis antara pihak sekolah dan orangtua.

Lantas, apa saja yang bisa Anda (sebagai orangtua) berikan untuk mewujudkan keberhasilan pendidikan anak?

Dari ilustrasi penjelasan di atas, tulisan ini bertujuan mendeskripsikan bentuk dukungan orangtua terhadap masa depan anak.

\section{PEMBAHASAN}

Beberapa dukungan orangtua terhadap masa depan seorang anak adalah sebagai berikut.

\section{Pilihkan sekolah sesuai dengan minat anak.}

Sebelum mendaftarkan si Kecil pada sekolah tertentu, cari informasi mengenai sekolah yang dituju yang disesuaikan dengan minat anak. Bila si Kecil memiliki minat yang besar terhadap bahasa asing, tidak ada salahnya bila Anda memasukkan si Kecil pada sekolah yang mengenalkan beberapa bahasa asing dalam pembelajarannya, atau pada ekstrakurikulernya. Selain itu, bila si Kecil suka terhadap seni, Anda bisa memasukkannya pada sekolah yang memiliki berbagai ekstrakurikuler seni yang menjadi minatnya. Kesesuaian minat anak dengan sekolah akan memudahkan Anda dalam mengembangkan 
potensi si Kecil. Selain itu, anak akan merasa senang bersekolah sesuai dengan minatnya.

\section{Penuhi kebutuhan sekolahnya.}

Sudah menjadi tanggung jawab dan kewajiban setiap orangtua untuk memenuhi kebutuhan sekolah anaknya. Kebutuhan sekolah si Kecil, mencakup peralatan sekolah dan biaya sekolah. Peralatan sekolah seperti buku-buku sekolah, tas, pensil, buku gambar, dan lain-lain. Kebutuhan sekolah anak, baik biaya dan peralatan sekolah tak bisa dikatakan murah. Beberapa orangtua menyiapkan biaya pendidikan untuk anak-anaknya dengan asuransi pendidikan bahkan sebelum anaknya bersekolah.

Masyarakat menjadi lebih berfikir ilmiah terhadap segala tindakan khususnya dalam bidang pendidikan dan pengajaran terhadap para generasi atau para remaja. Dahulu masyarakat desa Namlea tidak mengutamakan pendidikan karena masyarakat menganggap bahwa berpendidikan tinggi sangat menguras harta. Selain itu, dulu banyak para remaja yang tidak melanjutkan sekolah di perguruan tinggi karena belum adanya Universitas di Kabupaten Buru. Padahal dengan mengenyam pendidikan sampai ke perguruan tinggi, jika selesai akan mengubah aspek kehidupan baik kepada diri sendiri maupun ketika berada di masyarakat (Hatuwe et.al, 2021).

Pendidikan merupakan usaha manusia untuk menumbuhkan dan mengembangkan potensi-potensi pembawaan baik jasmani maupun rohani sesuai dengan nilai-nilai yang ada dalam masyarakat dan kebudayaan (Ihsan, 2011). Pendidikan bagi kehidupan manusia merupakan kebutuhan mutlak yang harus dipenuhi sepanjang hayat, tanpa pendidikan mustahil manusia dapat hidup berkembang sejalan dengan aspirasi (citacita) untuk maju dan sejahtera menurut konsep pandangan hidup mereka (Susiati, et.al, 2020).

\section{Dampingi anak belajar di rumah.}

Anak terkadang tidak langsung memahami materi pelajaran tertentu yang ia dapat di sekolah. Anda, sebagai orangtuanya, diharapkan dapat membantunya menuntaskan masalah tersebut. Saat di rumah, dampingi si Kecil belajar dan bantu si Kecil untuk memahami materi pelajaran yang tidak dikuasainya.

\section{Motivasi si Kecil untuk meraih cita-citanya melalui pendidikan.}

Pendidikan formal sangat penting bagi anak dalam meraih cita-citanya. Anda harus memotivasi si Kecil supaya rajin belajar dan bersekolah untuk meraih cita-cita yang diinginkannya. Contoh: “Adek katanya ingin jadi dokter ya? Kalau ingin jadi dokter, harus rajin belajar dan sekolah, supaya pintar dan cita-cita Adek tercapai"

\section{Ciptakan suasana nyaman dalam belajar.}


Ciptakan suasana rumah yang nyaman dan tenang sehingga anak dapat berkonsentrasi saat belajar, seperti: kecilkan volume televisi atau matikan televisi, dan cahaya yang cukup untuk belajar.

\section{Perhatian dan kasih sayang}

Perhatian dan kasih sayang orangtua kepada anaknya sangat berperan dalam mendukung keberhasilan pendidikan anak. Misalnya, saat anak kesulitan dalam belajar, orangtua segera mencari solusi untuk mengatasinya, saat anak mendapatkan masalah dengan teman-temannya orangtua juga dengan perhatian dan kasih sayangnya membantu menghadapi masalahnya.

\section{Menanamkan budi pekerti.}

Menanamkan budi pekerti tak dapat dilepaskan dari peran orangtua. Banyak nilai-nilai budi pekerti yang harus diajarkan kepada anak, seperti sopan dalam berkata, tidak berkata jorok, menyapa orang lain, menghormati dan/atau menghargai orang lain, dan lain-lain. Hal ini penting ditanamkan pada diri anak sejak dini sehingga mereka bukan hanya menjadi anak yang cerdas di sekolah, tetapi juga cerdas dalam bersikap dan bersopan santun.

Seperti dikutip dari laman Sahabat Keluarga Kemendikbud RI, 3 peran orangtua tersebut yaitu:

1. Orangtua sebagai trainer Bahasa umum, trainer adalah orang yang yang memberikan pelatihan berupa pengetahuan dan keterampilan. Ternyata peran ini sangat cocok bagi orangtua untuk mendidik anak terutama saat anak berusia 1-7 tahun. Di usia tersebut saat yang tepat memberikan pondasi kehidupan berupa pengetahuan dan keterampilan dasar. Misalnya pengetahuan mengenai perilaku atau nilai-nilai yang baik maupun yang buruk. Bisa pula dengan mengajarkan anak tentang toilet training. Peran orangtua ialah memberikan detail, cara yang baik bagaimana buang air.

2. Orangtua sebagai coach Arti dari coach sendiri yakni orang yang membantu seseorang mencapai tujuannya dengan memaksimalkan potensi dari dirinya. Seorang coach/pelatih ini akan mengajukan pertanyaan-pertanyaan sebagai sarana untuk mencapai tujuan. Orangtua menjadi coach saat si anak berada pada usia 8-21 tahun. Walaupun ditujukan pada anak-anak remaja, ilmu coaching bisa diterapkan pada usia anak berapapun. Pada peran ini, orangtua memaksimalkan potensi yang ada dalam diri anak untuk mencapai tujuan tertentu. Untuk bisa memaksimalkan potensi diri anak, tentu orangtua harus mengetahui dan bisa menggali potensi yang dimiliki anaknya. Ketika mencapai usia 15 tahun, anak sudah menginjak kedewasaan. Maka orangtua hanya perlu mendampingi dengan pertanyaan mendalam yang akan memaksimalkan potensi anak. Keterampilan coaching ini sangat bermanfaat bagi orangtua dalam hal menemani tumbuh kembang anak. Secara alamiah, sebenarnya orangtua 
sudah bertindak sebagai coach. Jika proses alamiah ini ditingkatkan dengan ilmu dan keterampilan, diharapkan proses yang dilakukan menjadi lebih baik dan lebih efektif.

3. Orangtua sebagai terapis Jika bahasa awam, terapis adalah orang yang memberikan terapi kepada kliennya dengan cara tertentu. Terapi diberikan pada seseorang yang dalam kondisi negatif. Peran orangtua disini, jika memiliki anak dengan mental lemah, kurang percaya diri, gugup, ragu, malas, trauma, depresi dan lain-lain, maka orangtua harus mampu melakukan segala hal agar anak jadi lebih baik dan maju. Orangtua menjadi terapis saat anak berusia remaja yang umumnya labil dan mencari identitas diri, sehingga kerap berperilaku yang tidak semestinya. Contohnya, anak mulai merasakan kesulitan dengan pelajaran tertentu, sehingga terkadang dia sampai malas sekolah. Orangtua juga bisa menjadi terapis terutama ketika memiliki anak berkebutuhan khusus, kecanduan gawai yang akut, kecanduan pornografi, dan perilaku negatif lainnya.

Meskipun orang tua tidak berkuasa mengubah hati anak, namun orang tua dapat membentuk karkater anak, di rumah terdapat pendisiplinan dan kekuasaan yang dapat menjadi alat efektif orang tua untuk penggemblengan anak. Keberhasilan dan kualitas pendidikan keluarga sangat ditentukan oleh beberapa faktor. Faktor ini dapat diklasifikasikan ke dalam dua hal, yaitu penciptaan iklim belajar dalam keluarga dan kualitas kemampuan orang tua dalam melaksanakan proses pendidikan.

Semakin kondusif iklim belajar dalam lingkungan keluarga, semakin berhasil pendidikan keluarga tersebut. Semakin tinggi kualitas kemampuan orang tua dalam melaksanakan pendidikan keluarga, semakin berhasil pendidikan keluarga tersebut. Salah satu pendekatan pendidikan yang ampuh bagi anak adalah mendidik anak dengan moral, mendidik dengan teladan dan mendidik anak dengan akhlak mulia. Bagaimanapun, apabila orang tua yang tidak menghasilkan teladan agung yang berharga bagi anaknya, tidak akan pernah memberikan pengaruh apa pun untuk diingat dan di ikuti dengan bangga dan sepenuh hati oleh keturunannya.

Maka, orang tua harus memiliki wibawa dan kasih sayang serta keiikhlasan sebagai orang tua bagi anaknya, sesuatu yang unik dan berbeda dibandingkan orang tua lainnya yang memiliki daya tarik yang begitu kuat sehingga anak ingin terusmenerus mendekat, bersama dan belajar. Demikian pula, seorang anak yang tidak belajar dan menyimpan keteladanan yang diwariskan orang tua kepadanya dan meneruskannya kembali kepada orang lain tidak akan pernah cukup mampu memberikan dampak bagi sekelilingnya. 


\section{DAFTAR PUSTAKA}

Iye, R., \& Susiati, S. (2018). NILAI EDUKATIF DALAM NOVEL SEBAIT CINTA DI BAWAH LANGIT KAIRO KARYA MAHMUD JAUHARI ALI (Educative Values in Sebait Cinta di Bawah Langit Kairo by Mahmud Jauhari Ali). Sirok Bastra, 6(2), 185-191.

Ritzer, G. (2014). Teori Sosiologi Modern. Terjemahan. Jakarta: Kencana Prenadamedia Group.

Susiati, S., Masniati, A., Tuasalamony, K., Hatuwe, R. S. M., Tahir, S. Z. B., Tenriawali, A. Y., \& Marasabessy, R. N. (2020). MEMBANGUN KETAHANAN RELEGIUS ANAK MELALUI ACTIVE PARENTAL INVOLVEMENT. Jurnal Islam Nusantara, 4(1), 111-125.

Susiati, \& Taufik. (2019). Nilai Pembentuk Karakter Masyarakat Wakatobi Melalui Kabhanti Wa Leja. Jurnal Totobuang, 7(1), 117-137.

Susiati, S., Iye, R., \& Suherman, L. O. A. (2019). Hot Potatoes Multimedia Applications in Evaluation of Indonesian Learning In SMP Students in Buru District. ELS Journal on Interdisciplinary Studies in Humanities, 2(4), 556-570.

Susiati, S., Masniati, A., \& Iye, R. (2021). Kearifan Lokal Dalam Perilaku Sosial Remaja Di Desa Waimiting Kabupaten Buru. Sang Pencerah: Jurnal Ilmiah Universitas Muhammadiyah Buton, 7(1), 8-23.

Susiati, S., Tenriawali, A. Y., Nursin, N., Nacikit, J., \& Mukadar, S. (2020). NILAI EDUKASI DALAM NOVEL PARTIKEL KARYA DEWI LESTARI:(The Value of Education in Particle Novels by Dewi Lestari). Uniqbu Journal of Social Sciences, 1(3), 176183.

Susiati, S. (2020). Nilai Budaya Suku Bajo Sampela Dalam Film The Mirror Never Lies Karya Kamila Andini.

Susiati, S., Tenriawali, A. Y., Nursin, N., Nacikit, J., \& Mukadar, S. (2020). NILAI EDUKASI DALAM NOVEL PARTIKEL KARYA DEWI LESTARI:(The Value of Education in Particle Novels by Dewi Lestari). Uniqbu Journal of Social Sciences, 1(3), 176183.

Tuasalamony, K., Hatuwe, R. S. M., Susiati, S., Masniati, A., \& Marasabessy, R. N. (2020). PENGEMBANGAN PENDIDIKAN KARAKTER DI SEKOLAH DASAR NEGERI 5 NAMLEA. Pedagogy, 7(2), 81-91.

Hatuwe, Rahma Satya Masna., Tuasalamony, Kurniati., Susiati, Susiati, Masniati, Andi., dan Yusuf, Salma. (2021). MODERNISASI TERHADAP PERUBAHAN SOSIAL MASYARAKAT DESA NAMLEA KABUPATEN BURU. Nusantara: Jurnal Ilmu Pengetahuan Sosial, 8(1), 84-96 
